\title{
Oral Health Knowledge and Attitudes of Elementary Schoolteachers in Michigan
}

Paul Lang, DDS, $\mathrm{MPH}^{\star}$

Associate Professor

Marilyn W. Woolfolk, DDS, MPH

Assistant Professor

Barbara Wirth Faja, MPH

Research Associate

Department of Prevention and Health Care School of Dentistry, University of Michigan

Ann Arbor, MI 48109-1078

\begin{abstract}
Teachers at elementary schools in two areas (urban and rural) of Michigan were surveyed to determine their sources of information about oral health and their knowledge and attitudes about dental diseases and disease prevention. Questionnaires were completed by 404 teachers (62\% response rate). More than 80 percent of respondents from both areas were female. Demographic characteristics that were significantly different between groups included: median ages of urban and rural respondents $(\mathrm{P}<.01)$, median numbers of years in teaching $(\mathrm{P}<.01)$, and median years in residence $(\mathrm{P}<.03)$. Despite these differences, responses to the questionnaire varied little. For both groups, the most frequently cited sources of information about dental health were dentist's office (82\%), followed by magazines and books (74\%). The teachers considered preventing tooth decay as the most important reason for good oral hygiene. When asked to rank the effectiveness of ten methods of preventing caries in children, teachers ranked efficacious methods such as fluoridated water and pit and fissure sealants lower than making regular dental visits and reducing intake of sugared foods. Asked to rank the most effective method for children to receive fluoride, urban respondents ranked fluoridated water first, while rural respondents ranked this measure third. Findings suggest that teachers' knowledge about oral health and current methods of prevention is incomplete, is inaccurate in some instances, and varies little by geographic area.
\end{abstract}

Key Words: elementary schoolteachers, knowledge, attitudes, oral health education

Elementary schools possess several inherent qualities that make them suitable for the presentation of oral health information. Foremost is the fact that children,

* Send correspondence and reprints to Dr. Lang. Manuscript received: $4 / 28 / 88$; returned to author for revision: $6 / 3 / 88$; accepted for publication: $6 / 20 / 88$. the potential recipients of such presentations, spend a considerable amount of time in this setting (1). Moreover, children can be reached at a time when their health habits are forming (2) and programs can be made available to all children, including those who may not have access to other sources of health information, such as the dental office (3).

Health education programs in schools may be conducted by external groups such as public health agencies, dental societies, and private dental offices, or be provided internally by school nurses and teachers. The advantages of using school personnel are the potential for improved continuity of instruction and lowered cost of the service. A possible disadvantage, however, is that such individuals may not have adequate preparation and knowledge to provide health education. Among these personnel, teachers may be unprepared to instruct their students about health and be unfamiliar with current oral health concepts.

Several investigators suggest possible reasons for a lack of preparedness of teachers and provide some supporting evidence. Surveying health education requirements in selected American universities, Kittleson and Ragon discovered that only 44 percent of education majors were required to complete a general health course (4). An inspection of available health textbooks for training teachers revealed a dearth of material on dental care and found that when information was provided, it was inconsistent and inadequate (5). Findings from a recent survey (6) that asked future elementary teachers about their knowledge of oral health and preventive programs indicated that respondents were poorly informed about prevention of oral disease and cautious about accepting supervisory roles in preventive programs. Once in the work setting, do teachers gain knowledge about oral health and acquire enthusiasm for program participation? The answer is no, according to two surveys of working teachers.

Elementary schoolteachers in Kentucky could identify traditional dental concepts of brushing frequency and toothbrush placement, but lacked understanding of newer methods of plaque control (7). In Minnesota, Loupe and Frazier (3) found that teachers were misin- 
formed about the purposes of oral hygiene care and the relative effectiveness of measures to prevent dental caries. Additionally, respondents were less inclined to accept administrative responsibilities in school oral health programs. The limited literature that reports teachers' knowledge and attitudes suggests that further investigation is warranted to confirm previous findings and to determine whether regional differences occur in the acquisition of oral health concepts by these individuals. Periodic surveys also can assess whether dissemination of new information about preventive agents is progressing.

The objectives of this study were to (1) evaluate the oral health knowledge and attitudes of elementary schoolteachers in two areas of Michigan, (2) identify teachers' sources of health information, and (3) ascertain how teachers perceived their roles in promoting oral health.

\section{Methods}

All elementary schoolteachers in two areas of Michigan, an urban community (100,000 people) with 26 schools and a rural area with 23 schools serving children from 46 communities, comprised the sample for this investigation. A questionnaire was constructed using questions from previous investigations $(3,6)$ and focusing on four topics: sources of information about oral health, personal oral hygiene, prevention of dental diseases, and the role of the teachers in promoting oral health. Teachers' age, sex, teaching experience, and dental experience also were collected.

Questionnaires were sent to all classroom teachers $(n=649)$ in the two areas via school mail between January and April of 1986; anonymity was assured to participants. The first mailing was followed by a reminder letter, a second mailing of the questionnaire, and a final letter. Data analysis generated frequency distributions and mean rankings of responses. Differences in responses based upon locality and length of teaching experience of a respondent were assessed using chisquare statistics. When no differences were identified, data were analyzed collectively. Length of teaching experience was stratified into three levels: ten years or less, 11 to 20 years, and more than 20 years.

\section{Results}

Questionnaires were completed by 404 elementary schoolteachers, for a response rate of 62 percent. Characteristics of respondents are displayed in Table 1. Most respondents were female. Respondents from the urban area were older, had taught school longer, and had resided in their community longer than rural respondents. About 90 percent of all respondents reported visiting the dentist within the last year. The most common reason for a visit was for a checkup and cleaning, which was reported by about 80 percent of respondents.

Sources of Information About Oral Health. Table 2 displays teachers' sources of information about oral health by frequency of response. Sources of information did not differ greatly between the two areas and thus are reported collectively. The dental office was cited most often by respondents, followed by media (magazines and books, newspapers, television, and radio). When asked to select the single source that provided the most information, 45 percent of the teachers selected the dental office, while about 28 percent selected magazines and books.

Personal Oral Hygiene. Respondents were asked to rank, in order of importance, reasons for maintaining good oral hygiene (Table 3). Preventing tooth decay was ranked by 65 percent of the teachers as the most important reason, followed by preventing gum disease $(52 \%)$. Least important reasons included reducing dental costs and setting an example for children. The rank-

TABLE 1

Demographic Characteristics of the Study Population

\begin{tabular}{|c|c|c|c|c|c|}
\hline \multirow[b]{2}{*}{ Characteristic } & \multicolumn{2}{|c|}{ Urban } & \multicolumn{2}{|c|}{ Rural } & \multirow[b]{2}{*}{ Signif. } \\
\hline & $\%$ & $n$ & $\%$ & $n$ & \\
\hline \multicolumn{6}{|l|}{ Sex } \\
\hline Male & 17.0 & 23 & 12.8 & 34 & $\mathrm{NS}^{*}$ \\
\hline Female & 83.0 & 112 & 87.2 & 232 & $N S^{*}$ \\
\hline Median age & \multicolumn{2}{|c|}{48 years } & \multicolumn{2}{|c|}{40 years } & $P<.01^{* *}$ \\
\hline $\begin{array}{l}\text { Median years in } \\
\text { teaching }\end{array}$ & \multicolumn{2}{|c|}{19} & \multicolumn{2}{|c|}{14} & $P<.01^{* *}$ \\
\hline $\begin{array}{l}\text { Median years in } \\
\text { residence }\end{array}$ & \multicolumn{2}{|c|}{20} & \multicolumn{2}{|c|}{15} & $P<.03^{* *}$ \\
\hline
\end{tabular}

${ }^{*}$ Chi-square test.

${ }^{* *}$ Mann Whitney $U$ test.

TABLE 2

Sources of Oral Health Information

\begin{tabular}{lcc}
\hline Source & $\%$ & $n^{*}$ \\
\hline Dental office/clinic & 82.3 & 325 \\
Magazines or books & 74.4 & 294 \\
Newspapers & 53.9 & 213 \\
TV or radio & 52.4 & 207 \\
Friends/neighbors/family & 38.2 & 151 \\
Physician's office/health clinic & 38.0 & 150 \\
\hline
\end{tabular}

*More than one response allowed.

TABLE 3

Reasons for Maintaining Good Oral Hygiene $(n=394)$

\begin{tabular}{lc}
\hline Reasons & $\begin{array}{c}\text { Mean } \\
\text { Ranking* }\end{array}$ \\
\hline To prevent tooth decay & 1.44 \\
To prevent gum disease & 2.09 \\
To prevent bad breath & 3.86 \\
To enhance appearance & 4.02 \\
To reduce dental care costs & 4.58 \\
To set an example for children & 5.00
\end{tabular}

${ }^{*}$ Most important (1) to least important (6). 
TABLE 4

Ranking of Methods of Caries Prevention in Children

\begin{tabular}{lcccc}
\hline Methods & $\begin{array}{c}\text { Overall } \\
\text { Mean Ranking }\end{array}$ & $n$ & Urban & Rural \\
\hline Make regular dental visits & 1.28 & 398 & 1 & 1 \\
Reduce sugar consumption & 1.49 & 401 & 2 & 2 \\
Use dental floss at least once a day & 1.58 & 380 & 3 & 4 \\
Brush with fluoride toothpaste & 1.60 & 397 & 4 & 3 \\
Have fluoride applied professionally & 1.86 & 370 & 6 & 5 \\
Drink fluoridated water & 1.91 & 363 & 5 & 6 \\
Have fissure sealants applied to teeth & 2.07 & 160 & 7 & 7 \\
Use fluoride mouthrinse & 2.26 & 329 & 8 & 8 \\
Take fluoride tablets daily & 2.38 & 208 & 9 & 9 \\
Brush regularly without toothpaste & 3.04 & 341 & 10 & 10 \\
\hline
\end{tabular}

*Very effective (1) to not effective (4).

TABLE 5

Knowledge about Fluoride

\begin{tabular}{|c|c|c|c|c|c|c|}
\hline \multirow[b]{2}{*}{ Item } & \multicolumn{2}{|c|}{ Correct } & \multicolumn{2}{|c|}{ Incorrect } & \multicolumn{2}{|c|}{ Don't Know } \\
\hline & $\%^{*}$ & $n$ & 76 & $n$ & $\%$ & $n$ \\
\hline $\begin{array}{l}\text { Fluoride makes tooth enamel more } \\
\text { resistant to decay }(\mathrm{T}) \text {. }\end{array}$ & 95.7 & 381 & 1.3 & 5 & 3.0 & 12 \\
\hline $\begin{array}{l}\text { Fluoride shows where plaque is on } \\
\text { the teeth }(F) \text {. }\end{array}$ & 76.9 & 310 & 3.0 & 12 & 20.1 & 81 \\
\hline Fluoride cleans the teeth $(F)$ & 76.3 & 306 & 13.5 & 54 & 10.2 & 41 \\
\hline Fluoride makes teeth whiter $(F)$ & 61.0 & 244 & 6.8 & 27 & 32.3 & 129 \\
\hline $\begin{array}{l}\text { Fluoride cuts down on bacteria in } \\
\text { the mouth }(\mathrm{T}) \text {. }\end{array}$ & 37.2 & 149 & 37.4 & 150 & 25.4 & 102 \\
\hline $\begin{array}{l}\text { Fluoride is an essential nutrient for } \\
\text { bones and teeth }(\mathrm{T}) \text {. }\end{array}$ & 33.5 & 134 & 42.3 & 169 & 24.3 & 97 \\
\hline $\begin{array}{l}\text { Fluoride helps repair small cavities } \\
\text { in teeth }(T) \text {. }\end{array}$ & 4.0 & 16 & 82.6 & 333 & 13.4 & 54 \\
\hline
\end{tabular}

*Percents may not add to $100 \%$ due to rounding.

ings of reasons for personal oral hygiene were similar for urban and rural teachers.

Prevention of Oral Disease. Respondents were asked to rate the effectiveness of various actions in the prevention of tooth decay in children. In Table 4, the regimens are listed by mean ranking by all respondents on a four-point scale ranging from most effective to least effective. Relative rankings from 1 to 10 are also displayed by area. Having regular dental visits and reducing the consumption of sugared foods were considered to be the two most effective methods of caries prevention. Drinking fluoridated water and having fissure sealants applied to teeth were ranked fifth and seventh by urban teachers, and sixth and seventh by rural teachers. Both groups ranked using dental floss daily and brushing with a fluoride toothpaste higher than drinking fluoridated water and sealant applications. The effectiveness of fissure sealants and fluoride tablets as preventive regimens was unknown by 59 percent and 48 percent of respondents, respectively.
Rankings of effectiveness were not related to the length of a respondent's teaching experience.

Teachers' responses to questions about fluoride did not vary greatly by area or by length of time in teaching. Responses are shown collectively in Table 5. Most respondents knew that fluoride makes tooth enamel more resistant to decay, does not clean the teeth, or show where plaque is on the teeth. Lack of knowledge was demonstrated most with regard to whether fluoride helps repair small cavities, is an essential nutrient, and helps cut down on bacteria in the mouth.

Table 6 displays, by area, schoolteachers' rankings of effective methods for children to receive iluoride. Responses by urban teachers demonstrated some incongruity when compared to rankings in Table 4 , as these teachers ranked drinking fluoridated water as most effective, followed by professionally applied fluorides and fluoride dentifrices. Rural teachers were more uniform in their rankings: fluoridated water was ranked in the middle for relative effectiveness. Both groups 
ranked fluoride tablets as a less effective method of receiving fluoride.

With respect to periodontal disease (Table 7), the distribution of responses from both areas was fairly similar. The teachers were knowledgeable about the relation of tooth loss to periodontal disease, and that it is a progressive disease leading to bone loss. About 70 percent of respondents correctly related good oral hygiene with the prevention of gum disease and the presence of plaque as a cause of periodontal disease. Fifty percent of the respondents were unsure if vitamins and sunlight prevented periodontal disease, and about 41

\section{TABLE 6}

Perceived Effectiveness of Fluorides for Children

\begin{tabular}{lc}
\hline Method & $\begin{array}{c}\text { Mean } \\
\text { Ranking* }\end{array}$ \\
\hline Urban teachers $(n=127)$ & \\
Fluoridated water & 1.96 \\
Professionally applied fluoride & 2.48 \\
Fluoride dentifrice & 2.63 \\
Fluoride mouthrinse & 3.89 \\
Fluoride supplements & 4.03 \\
Rural teachers ( $n=255)$ & \\
Fluoride dentifrice & 2.39 \\
Professionally applied fluoride & 2.60 \\
Fluoridated water & 2.67 \\
Fluoride supplements & 3.62 \\
Fluoride mouthrinse & 3.72 \\
\hline
\end{tabular}

* Most effective (1) to least effective (5). percent did not know if a virus caused the disease. Only half of the teachers knew that bleeding was an early sign of periodontal disease. The only significant deviation in responses between the two areas was for the question about the relation of good oral hygiene and gum disease. Rural teachers were more likely to answer incorrectly (chi-square test, $P<.001$ ). There were no differences in the distribution of responses based upon length of time in teaching.

Role of Teacher in Promoting Oral Health. Respondents were asked to indicate the extent of their agreement or disagreement with statements of responsibilities that are sometimes expected of schoolteachers (Table 8). A scale ranging from strongly agree to strongly disagree was used and then collapsed to agree/disagree. Respondents were more likely to accept responsibility for roles that did not involve loss of class time by students, out-of-school efforts, or direct supervision. In particular, the latter category was not considered by respondents to be a responsibility of teachers. The only difference found between urban and rural areas was for supervision of fluoride mouthrinsing, with rural teachers being more likely to accept supervisory responsibilities (chi-square test, $P<.01$ ). Length of time in teaching did not affect perceptions of responsibility by respondents.

\section{Discussion}

Differences in responses between urban and rural teachers were not found, suggesting that knowledge levels and attitudes may be similar among all schoolteachers regardless of school location. The consistency

TABLE 7

Knowledge about Periodontal Disease

\begin{tabular}{|c|c|c|c|c|c|c|}
\hline \multirow[b]{2}{*}{ Item } & \multicolumn{2}{|c|}{ Correct } & \multicolumn{2}{|c|}{ Incorrect } & \multicolumn{2}{|c|}{ Don't Know } \\
\hline & $\%^{*}$ & $n$ & $\%$ & $n$ & $\%$ & $n$ \\
\hline $\begin{array}{l}\text { After age } 35, \text { tooth loss is more } \\
\text { attributable to tooth decay than to } \\
\text { gum disease }(\mathrm{F}) \text {. }\end{array}$ & 85.1 & 343 & 5.0 & 20 & 9.9 & 40 \\
\hline $\begin{array}{l}\text { Periodontal disease can be progres- } \\
\text { sive, leading to loss of bone that } \\
\text { supports the teeth }(\mathrm{T}) \text {. }\end{array}$ & 84.1 & 338 & 4.0 & 16 & 11.9 & 48 \\
\hline $\begin{array}{l}\text { Good oral hygiene (brushing and } \\
\text { flossing) is more important in } \\
\text { preventing gum disease than in } \\
\text { preventing tooth decay }(\mathrm{T}) \text {. }\end{array}$ & 69.6 & 279 & 16.0 & 64 & 14.5 & 58 \\
\hline $\begin{array}{l}\text { The cause of gum disease is the } \\
\text { presence of dental plaque (T). }\end{array}$ & 68.4 & 275 & 14.9 & 60 & 16.7 & 67 \\
\hline $\begin{array}{l}\text { Periodontal disease is caused by a } \\
\text { virus }(\mathrm{F}) \text {. }\end{array}$ & 59.3 & 237 & 7.0 & 28 & 33.8 & 135 \\
\hline $\begin{array}{l}\text { Vitamins and sunlight can prevent } \\
\text { periodontal disease }(F) \text {. }\end{array}$ & 49.8 & 199 & 14.0 & 56 & 36.3 & 145 \\
\hline $\begin{array}{l}\text { Slight bleeding upon brushing is an } \\
\text { early sign of periodontal disease } \\
\text { (T). }\end{array}$ & 49.4 & 198 & 37.2 & 149 & 13.5 & 54 \\
\hline
\end{tabular}

*Percents may not add to $100 \%$ due to rounding. 
TABLE 8

Perceived Role of Teacher in Promoting Oral Health

\begin{tabular}{|c|c|c|c|c|c|c|}
\hline \multirow[b]{2}{*}{ Teachers Should } & \multicolumn{2}{|c|}{ Agree } & \multicolumn{2}{|c|}{ Disagree } & \multicolumn{2}{|c|}{ No Opinion } \\
\hline & $\%^{*}$ & $n$ & $\%$ & $n$ & $\%$ & $n$ \\
\hline $\begin{array}{l}\text { Refer students with dental } \\
\text { problems to the school nurse. }\end{array}$ & 90.1 & 356 & 5.6 & 22 & 4.3 & 17 \\
\hline $\begin{array}{l}\text { Advise students regarding } \\
\text { advertising of commercial sugar } \\
\text { products. }\end{array}$ & 85.7 & 342 & 11.5 & 46 & 2.8 & 11 \\
\hline $\begin{array}{l}\text { Instruct students about scientif- } \\
\text { ically valid methods to prevent } \\
\text { oral diseases. }\end{array}$ & 85.6 & 339 & 9.8 & 39 & 4.5 & 18 \\
\hline $\begin{array}{l}\text { Instruct students about public } \\
\text { health measures such as } \\
\text { community water fluoridation. }\end{array}$ & 83.4 & 332 & 11.6 & 46 & 5.0 & 20 \\
\hline $\begin{array}{l}\text { Allow class time for students to get } \\
\text { dental care. }\end{array}$ & 56.4 & 224 & 37.0 & 147 & 6.5 & 26 \\
\hline $\begin{array}{l}\text { Be actively involved in community } \\
\text { efforts to improve students' oral } \\
\text { health. }\end{array}$ & 49.7 & 196 & 34.0 & 134 & 16.2 & 64 \\
\hline $\begin{array}{l}\text { Supervise the use of weekly } \\
\text { fluoride mouthrinsing in class. }\end{array}$ & 9.5 & 38 & 84.7 & 337 & 5.8 & 23 \\
\hline $\begin{array}{l}\text { Supervise daily brushing and } \\
\text { flossing in the classroom. }\end{array}$ & 6.0 & 24 & 91.3 & 365 & 2.8 & 11 \\
\hline
\end{tabular}

*Percents may not add to $100 \%$ due to rounding.

of findings becomes more apparent when the results of other investigations are compared to these data. Sources of oral health information for both future teachers (6) and working teachers were the same: the most frequently reported source and the source that provided the most information for both groups were the dental office/clinic. This finding concurs with results of an opinion study by $\mathrm{O}^{\prime} \mathrm{Neill}(8)$, who found that in a national probability sample of 1,003 persons, 64 percent of respondents used their dentists as a source of information about oral health. Further comparisons of working teachers with student teachers found that the former reported more use of media as sources of information than did the students who reported using friends/ neighbors/family as sources.

Rankings of reasons for maintaining good oral hygiene show the similarities among teachers-to-be and employed teachers and among teachers in different states (3). Misunderstanding about the relative importance of oral hygiene in the prevention of caries appears to be quite prevalent among all groups, and has not changed with time. Moreover, setting an example for students was not considered an important reason to maintain good oral hygiene by any of the groups of teachers.

The low ranking of such effective caries preventive methods as fluoridated water and fissure sealants highlights and confirms the apparent gap that exists between public and scientific knowledge $(8,9)$. It seems also that awareness of these preventive methods is not affected by locality, as rankings by urban and rural teachers were not appreciably different. Only when methods of receiving fluoride were evaluated for their effectiveness in children did variations become apparent, with urban teachers ranking fluoridated water first, while rural teachers ranked fluoride dentifrice first. As respondents were not asked about their community's fluoridation status, it is unknown whether there was a relation between knowledge of that status and greater awareness of the benefits of fluoridated water.

Elementary schoolteachers' knowledge about fluorides and periodontal disease was found to be incomplete and sometimes inaccurate. Respondents had correct information about the ability of fluoride to improve caries resistance. Incorrect knowledge or a lack of knowledge was more evident regarding fluoride's role as an essential nutrient, in decreasing bacteria, and in remineralization. Information about these latter qualities of fluoride apparently has not been disseminated to the public, even though there is scientific evidence confirming these attributes of fluoride.

That respondents were uncertain about the purpose of oral hygiene is clear. When questioned about periodontal disease, approximately 70 percent of the teachers correctly answered that oral hygiene was more important in preventing gum disease than tooth decay. Yet when asked about personal oral hygiene, teachers ranked prevention of tooth decay as the most important reason for maintaining oral hygiene. This finding demonstrates the persistence of "conventional dental wisdom" that also was found in the survey of Kentucky teachers (7).

The degree of willingness to accept roles that pro- 
mote oral health seems to be commensurate with teachers' perceptions of the time requirements needed to accomplish the particular activity. Respondents were less likely to agree to allow students to use class time to receive dental care or to be involved in community efforts to improve oral health. Activities requiring supervision-mouthrinsing, brushing, and flossingwere not considered to be under the purview of teachers. This confirms the observation of other investigators $(3,10)$. Glasrud and Frazier (6) reported that future teachers were more willing to be involved in community efforts and to allow time for dental treatment, as about 70 percent of them agreed that these were responsibilities of teachers. Additionally, about onequarter of the future teachers agreed that teachers should supervise preventive activities. Teachers' attitudes toward these responsibilities may change quickly once they are employed. In the present investigation, perception of responsibilities were not affected by the length of time in teaching. Michigan teachers with the least teaching experience had perceptions of responsibilities similar to teachers with more years of experience. The cross-sectional design of this study did not allow investigators to determine why or when teachers' attitudes changed once they entered the classroom. This phenomenon may be worth investigating further to determine if the positive attitudes exhibited by future teachers toward such responsibilities can be sustained. Resistance to accepting supervisory responsibilities also may be the result of teachers' perceptions that this activity should be performed by other employees, such as the school nurse (11). A sign of encouragement, nonetheless, is that some of the rural schools had mouthrinsing programs, and that rural teachers were more willing to accept supervisory responsibilities. Having teachers observe the operation of such programs might allay their apprehensions about supervision.

\section{"Results reveal that teachers have fragmentary knowledge about the reasons for oral hygiene, effective caries preventive agents, and prevention of periodontal disease."}

Results reveal that teachers have fragmentary knowledge about the reasons for oral hygiene, effective caries preventive agents, and prevention of periodontal disease. Furthermore, teachers' willingness to be involved with disease prevention activities will probably be related to the time commitment required for the activity. Additionally, findings confirm that changes in knowledge and attitudes may not occur rapidly $(3,7)$, nor will changes necessarily come about once teachers begin working (6). The enthusiasm of new teachers for in- volvement in oral health activities may quickly be dampened by the realities of working. Given these observations, dental health professionals should seek more opportunities to educate and interact with teachers.

Early intervention may be achieved in schools of education. Supplying faculty with current teaching materials on dental health may be one approach. Capitalizing on the enthusiasm of future teachers for being involved in community health efforts and their guarded interest in supervisory roles may be another avenue. Future teachers should be encouraged to partake in oral health promotion activities and to observe effective ongoing preventive programs such as those utilizing fluoride mouthrinsing, fluoride tablets, or sealants. Participation in these endeavors during student teaching might increase the acceptance of such responsibilities after employment begins.

Helping to write or revise school health education teaching curricula at local or state levels can provide an opportunity to incorporate current views about dental disease and prevention. Advocates for oral health must be present to guarantee that this aspect of wellness is equally represented among such diverse issues as child safety, substance abuse, and mental health (12). Ensuring representation in health curricula is only part of the task. The content of a dental component must receive periodic scrutiny to verify that information is topical and scientifically accurate.

Providing in-service programs for teachers and guiding school education programs are other approaches that might be utilized to raise oral health awareness. For example, health promotion programs for school personnel may be appropriate forums for in-service training, as improvement of oral health complements typical program goals of fitness and well-being $(13,14)$. Teachers may also seek community sources for program content of school health fairs (15). The dental public health professional can act as a resource by providing educational materials or by participating in the program.

Where preventive programs exist in schools, teachers and students should be reminded of the reasons for such programs and their beneficial effects. While program participants may learn something about oral health and prevention (16), the extent to which teachers and nonparticipating students may acquire knowledge from these programs is unknown. Having periodic schoolwide presentations as part of a preventive program might improve awareness of all groups.

Increasing the oral health knowledge of elementary schoolteachers provides an opportunity to educate an important segment of the public that has access to large populations of young people. By providing suitable education materials and by engaging in health promotion activities, dental public health professionals can interact with teachers in a mutually beneficial manner.

\section{Acknowledgments}

The authors thank P. Jean Frazier and Patricia H. Glasrud for their contributions to this project. 


\section{References}

1. Silversin JB, Kornacki MJ. Controlling dental disease through prevention: individual, institutional, and community dimensions. In: Cohen LK, Bryant PS, eds. Social sciences and dentistry, a critical bibliography. Vol II. London: Quintessence, 1984:145-201.

2. Breckon DJ, Harvey JR, Lancaster RB. Community health education. Settings, roles, and skills. Rockville: Aspen Systems Corp, 1985:255.

3. Loupe MJ, Frazier PJ. Knowledge and attitudes of schoolteachers toward oral health programs and preventive dentistry. J Am Dent Assor 1983 Aug; 107:229-34

4. Kittleson MJ, Ragon BM. A survey of health education requirements in American universities. J School Health 1984 Feb;54:91-2.

5. Freed JR, Goldstein MS. Dental health: what is being taught to college students. J Am Dent Assoc 1976 May;92:940-5.

6. Glasrud PH, Frazier PJ. Future elementary schoofteachers' knowledge and opinions about preventive dentistry. I Public Health Dent 1988 Spring;48:74-80.

7. Mullins R, Sprouse W. Dental health knowledge of elementary schoolteachers in Bowling Green, Kentucky, 1972. J Am Soc Prev Dent 1973 Jan-Feb;3:60-5.
8. O'Neill HW. Opinion study comparing attitudes about dental health. J Am Dent Assoc 1984 Dec;109:910-5.

9. Frazier PJ. Current utilization patterns of oral hygiene practices. Response. In: Löe H, Kleinman DV, eds. Dental plaque control measures and oral hygiene practices. Oxford: IRL Press Ltd, 1986:72-90.

10. Boyer ME. Classroom teachers' perceived role in dental health education. J Public Health Dent 1976 Fall;36:237-43.

11. Coombs JA, Silversin JB, Rogers EM, Drolette ME. The transfer of preventive health technologies to schools: a focus on implementation. J Soc Sci Med 1981;15A:789-99.

12. Michigan model for comprehensive school health education. Lansing, Michigan Department of Public Health, 1986 (12 pp mimeo).

13. Falck VT, Kilcoyne ME. A health promotion program for school personnel. J School Health 1984 Aug;54:239-43

14. McKenzie JF. Twelve steps in developing a school site health education/promotion program for faculty and staff. J School Health 1988 Apr;58:149-53.

15. Bays CT. The elementary school health fair: a process involving the whole school in health education. I School Health 1986 Oct:56:339-41.

16. Russell BA, Horowitz AM. Oral health knowledge and practices of sixth grade students. Am Pub Health Assoc 114th annual meeting, Program and Abstracts 1986:3.

\section{Thank You}

I would like to extend my heartiest thanks to all the persons who reviewed manuscripts for the Journal dur- ing the past year. Your thoughtful and timely reviews are appreciated by Editor and authors alike.

\author{
Steven Adair \\ Myron Allukian \\ James Bader \\ David Banting \\ Ronald Billings \\ Lester Block \\ John Brown \\ Brian Burt \\ Jack Caton \\ Gregory Connolly \\ Naham Cons \\ Steve Corbin \\ Marsha Cunningham \\ John Daniel \\ Neville Doherty \\ Chet Douglass \\ William Driscoll \\ Michael Easley \\ Stephen Eklund \\ Cas Evans \\ John Featherstone
}

\author{
James Freed \\ Barbara Gerbert \\ Jay Gershen \\ Helen Gift \\ Patricia Glasrud \\ John Greene \\ Alice Horowitz \\ Herschel Horowitz \\ Ronald Hunt \\ Amid Ismail \\ Robert Isman \\ Joanna Jenny \\ Øivind Jensen \\ David Johnsen \\ David Johnston \\ Saul Kamen \\ Cheryl Kelley \\ Asuman Kiyak \\ Jayanth Kumar \\ W. Paul Lang \\ Steven Levy
}

\author{
Donald Lewis \\ Dolores Malvitz \\ Irwin Mandel \\ William McHugh \\ Peter Milgrom \\ John Molinari \\ Alvin Morris \\ Linda Niessen \\ Mata Nikias \\ John Odom \\ Howard Proskin \\ Lou Ripa \\ Susan Sanzi-Schaedel \\ Lin Saunders \\ Mark Siegal \\ Phil Swango \\ Lisa Tedesco \\ Margaret M. Walsh \\ Jane Weintraub \\ Robert Weyant \\ Joe Yacovone
}

Special thanks also go to Jean Frazier, whose persistence and expertise have been responsible for an outstanding Book Review section.

Lastly, I would like to thank the two people with whom I work most closely in preparing the Journal for publication: Betty Guenther, who handles all the de- tails here in Rochester, and Gabriele Glang, who, as Production Manager, is the person ultimately responsible for what you get and when you get it. Their skills and hard work are deeply appreciated. 